Marcel Marcano-Lozada ${ }^{1 *}$, Silvia Molero-Leon ${ }^{2}$

${ }^{1}$ Medical Microbiology Specialist, Medical Microbiology Unit, Angios Vascular Center \& Wound Clinic, Caracas, Venezuela.

${ }^{2}$ Internal Medicine Specialist, Angios Vascular Center \& Wound Clinic, Caracas, Venezuela

E-mail: marcelmarcano@gmail.com

*Corresponding author: Marcel Marcano-Lozada, 1Medical Microbiology Specialist, Medical Microbiology Unit, Angios Vascular Center \& Wound Clinic, Caracas, Venezuela.

Received Date: June 28, 2020; Accepted Date: July 28, 2020; Published Date: July 30, 2020.

Citation: - Marcano-Lozada M, Molero-Leon S, (2020) Combined non-orthodox therapy in the management of treatment-resistant infections due to Helicobacter pylori, Giardia duodenalis and Microsporidium sp. in a patient with chronic diarrhea, wasting syndrome and severe antibiotic allergy. Journal of Clinical Case Reports and Studies, 1(3): Doi: 10.31579/2690-8808/011

Copyright: ( ) 2020. Marcel Marcano-Lozada. This is an open-access article distributed under the terms of the Creative Commons Attribution License, which permits unrestricted use, distribution, and reproduction in any medium, provided the original author and source are credited.

We resume a clinical case submitted to the Medical Microbiology Unit due to the complexity of etiological diagnosis and previous health issues of the patient, and with the additional restriction in the use of anti-infective treatments for a severe allergic reaction record.

\section{Reference Summary}

The current illness of a 45-year-old female patient, born and raised in Caracas, Venezuela, known with a past of left hemicolectomy for abdominal trauma 4 years ago and subsequent intestinal malabsorption syndrome, who presents fetid diarrheal stools in number of 5-8 / day and burning pain sensation in epigastric region, and the last 6 months with significant weight loss $(30 \mathrm{~kg})$, was referral to our diagnostic facility care to being evaluated.

\section{Relevant background}

- Allergic to penicillin, macrolides \& quinolones (angioneurotic edema).

- Restitution of intestinal transit 1 year prior to the beginning of diarrheic manifestation, without apparent complications.

- Upper digestive endoscopy one year later the onset of diarrhea shows chronic antral gastritis (without H. pylori microbiological confirmation, but histologically suspected) treated with duo-therapy based on Metronidazole + Ranitidine.

- HIV Negative serology and negative tumor biomarkers.

\section{Physical exam}

- Patient in general regular conditions, wasted, weighing 40 $\mathrm{kg}$.

- Multiple abdominal scars.

- Pain to epigastric deep palpation.

Microbiological and Therapeutic Evolution
A microbiological study of feces is carried out, finding more than 100 spores of Microsporidium sp. (Kinyoun stain) -nor previously diagnose since the beginning of the diarrheic manifestations-, plus a positive Giardia duodenalis fresh mount stool exam. A Urea Breath Test with Charcoal 14 (UBT-C ${ }^{14}$ ) is performed and detect active gastric infection by $\mathrm{H}$. pylori

Considering the allergic background, treatment with Albendazole 400 $\mathrm{mg} / \mathrm{PO} / \mathrm{BID} / 4$ weeks is started together with Furazolidone 100 $\mathrm{mg} / \mathrm{PO} / \mathrm{QID}+$ Tetracycline $300 \mathrm{mg} / \mathrm{PO} / \mathrm{QID}$ scheme for 2 weeks associated with Omeprazole $20 \mathrm{mg} / \mathrm{PO} / \mathrm{BID}$ for 2 months.

In the coprological control examination at the end of the Albendazole treatment time, eradication of Giardia duodenalis is verified, with persistence of Microsporidium sp.; and it is indicated to extend Albendazole course for an additional 4 weeks.

The microbiological reassessment a month later shows persistence of microsporidia, and the control of urea breath test for $H$. pylori remains positive indicating therapeutic failure in the eradication of both microorganisms.

We decide to presented a non-orthodoxic therapeutic option using Nitazoxanide $500 \mathrm{mg} / \mathrm{PO} / \mathrm{BID}$ + Tetracycline $300 \mathrm{mg} / \mathrm{PO} / \mathrm{QID}$ for 3 weeks + Esomeprazole $40 \mathrm{mg} / \mathrm{PO} / \mathrm{OD}$ for 2 months, and the patient gives her writing consent for the new treatment schema.

In the post-treatment microbiological control, the eradication of Microsporidium sp. \& Helicobacter pylori is verified by Kinyoun stain without evidence of spores of microsporidia and a control negative UBT-C ${ }^{14}$, with complete clinical improvement. In addition, the patient didn't show any adverse reaction to the novel therapeutic combination.

\section{Conclusion}

For cases as special as the one presented, a deeper coprological exam (including Coccidia \& Microsporidia investigation) and non-invasive H. pylori diagnostic test (as UBT-C ${ }^{14}$ ) should be performed, moreover, where the antimicrobials allergies contraindicate the initial therapeutic lines. The knowledge of epidemiological susceptibility/resistance patterns is necessary, as it seems with the high resistance of $H$. pylori to metronidazole in Venezuela (> 70\%), plus, 
the limited effectiveness of treatment with Albendazole in microsporidia infection, leads to the use of alternative polyvalent antiparasitic drug that is usefully demonstrated, and the antibacterial effect of Nitazoxanide in the combination therapy for eradication of resistant $H$. pylori and its effective action in chronic diarrheic microsporidia disease, obligate to consider it use in the combination treatment of selected cases of multiple infective agents (when first line treatment were contraindicate or non-available).

\section{References}

1. Hoffman PS, Sisson G, Croxen MA, et al. (2007). Antiparasitic drug nitazoxanide inhibits the pyruvate oxidoreductases of Helicobacter pylori and selected anaerobic bacteria and parasites, and Campylobacter jejuni. Antimicrob Agents Chemother, 51 (3): 868-876.

2. Guttner Y, Windsor HM, Viiala CH, et al. (2003). Nitazoxanide in treatment of Helicobacter pylori: a clinical and in vitro study. Antimicrob Agents Chemother, 47 (12): 3780-3783.

3. Anderson VR, Curran MP. Nitazoxanide. (2007). A Review of its Use in the Treatment of Gastrointestinal Infections. Drugs, 67(13):1947-1947.

4. Megraud F, Occhialini A, Rossignol JF. (1998). Nitazoxanide, a Potential Drug for Eradication of Helicobacter pylori with No Cross- Resistance to Metronidazole. Antimicrob Agents Chemoter, 42(11):2836-2840.

5. Fox LM, Saravolatz L. Nitazoxanida: (2005). A New Thiazolide Antiparasitic Agent. Clin Infect Dis, 40:1173-1180.

6. Marcano-Lozada MJ, Molero León SE. (2009). "Experiencia terapéutica con nitazoxanida en diarrea crónica por microsporidios y criptosporidios en pacientes inmunocomprometidos oncológicos". Bol Venez Infectol, 20(1):12-16. 